DOI: https://dx.doi.org/10.33289/IJRPC.10.1.2020.10(12)

\title{
CRYSTAL GROWTH, STRUCTURE AND CHARACTERIZATION OF TUTTON'S SALT MIXED CRYSTALS - POTASSIUM MAGNESIUM MANGANESE SULFATE HEXAHYDRATE
}

\author{
G. Ramasamy* and J. Anandakumaran \\ Department of Chemistry, Annamalai University, \\ Annamalai Nagar - 608 002, Tamil Nadu, India.
}

\begin{abstract}
New mixed crystals of $\mathrm{K}_{2} \mathrm{Mg}_{0.78} \mathrm{Mn}_{0.22}\left(\mathrm{SO}_{4}\right)_{2} .6 \mathrm{H}_{2} \mathrm{O}$ (KMMS) were synthesized and grown from an equimolar mixture of the Tutton's salt $\mathrm{K}_{2} \mathrm{Mg}\left(\mathrm{SO}_{4}\right)_{2} \cdot 6 \mathrm{H}_{2} \mathrm{O}$ and $\mathrm{MnSO}_{4}$ by slow evaporation of the aqueous solution at room temperature. Crystal composition as determined by single crystal XRD analysis reveals that it belongs to the monoclinic system with $P 2_{1} / c$ space group and cell parameter values are, $\mathrm{a}=$ $6.1380 \oplus, \beta=12.2740 \oplus, \chi=9.0940 \oplus, \square=\left\{=90^{\circ}, \AA=104.81^{\circ}, \varsigma=662.33 \oplus^{3}, Z=4 . \quad\right.$ The coexistence of magnesium and manganese ions in the mixed crystal is confirmed by single crystal XRD analysis, atomic absorption spectroscopy, inductively coupled plasma and energy dispersive X-ray spectroscopy. Slight variations are observed in FT-IR and XRD of pure and mixed crystals. The surface morphology of the mixed crystal is studied by scanning electron microscopy. Thermogravimetric and differential thermal analysis curves show the purity of the substance. Large full width at half maximum value of diffraction curves in high resolution X-ray diffraction spectroscopy reveals the presence of misorientation in the lattice blocks because of the Mn(II)incorporation.
\end{abstract}

Keywords: Crystal structure, HRXRD, FT-IR spectroscopy, Tutton salt, KMMS.

\section{INTRODUCTION}

The compound under study potassium magnesium sulphate hexahydrate $\mathrm{K}_{2} \mathrm{Zn}\left(\mathrm{SO}_{4}\right)_{2} \cdot 6 \mathrm{H}_{2} \mathrm{O}$ belongs to a large number of isomorphous compounds with a general formula Me'Me" $\left(\mathrm{XO}_{4}\right)_{2} \cdot 6 \mathrm{H}_{2} \mathrm{O} \quad\left(\mathrm{Me}=\mathrm{K}, \mathrm{NH}_{4}{ }^{+}\right.$, $\mathrm{Rb}, \mathrm{Cs} ; \mathrm{Me}^{\prime \prime}=\mathrm{Mg}, \mathrm{Mn}, \mathrm{Co}, \mathrm{Ni}, \mathrm{Cu}, \mathrm{Zn} ; \mathrm{X}=\mathrm{S}$, Se) known as Tutton's salt ${ }^{1,2}$. These compounds are considered as potential conductors due to the existence of comparatively strong hydrogen bonds. They crystallize in the monoclinic system with space group $P 2_{1} / c$. The synthesis and characterization of potassium magnesium sulfate hexahydrate crystals have been carried out by Dhandapani et. al., ${ }^{3}$ Recently, we have investigated the crystal structure and characterization of zinc magnesium ammonium sulphate hexahydrate mixed crystals, $\quad \mathrm{Zn}_{0.54} \mathrm{Mg}_{0.46}\left(\mathrm{NH}_{4}\right)_{2}\left(\mathrm{SO}_{4}\right)_{2} \cdot 6 \mathrm{H}_{2} \mathrm{O}^{4}$ crystallized from equimolar mixture of $\mathrm{Zn}\left(\mathrm{NH}_{4}\right)_{2}\left(\mathrm{SO}_{4}\right)_{2} \cdot 6 \mathrm{H}_{2} \mathrm{O}$ and $\mathrm{Mg}\left(\mathrm{NH}_{4}\right)_{2}\left(\mathrm{SO}_{4}\right)_{2} \cdot 6 \mathrm{H}_{2} \mathrm{O}$. We have also investigated the growth, structure and spectral studies of a novel mixed crystal potassium zinc manganese sulfate, $\mathrm{K}_{2} \mathrm{Zn}_{0.84} \mathrm{Mn}_{0.16}\left(\mathrm{SO}_{4}\right)_{2} \cdot 6 \mathrm{H}_{2} \mathrm{O}$ (KZMS) ${ }^{5}$. Although extensive studies have been carried out on Tutton's salts, the growth, characterization and structure of $\mathrm{K}_{2} \mathrm{Mg}_{\mathrm{x}} \mathrm{Mn}_{(1-\mathrm{x})}\left(\mathrm{SO}_{4}\right)_{2} \cdot 6 \mathrm{H}_{2} \mathrm{O}$ mixed crystals have not been reported so far. As a part of our investigation on the studies of mixed crystals of Tutton's slats ${ }^{4,5}$ the present study was undertaken. The as-grown crystals have been characterized by FT-IR, XRD, HRXRD, SEM, EDS, AAS, UV- visible and thermal studies. 


\section{EXPERIMENTAL}

\subsection{Synthesis and crystal growth}

Pure KMMS was prepared by mixing equimolar concentrations of $\mathrm{K}_{2} \mathrm{Mg}\left(\mathrm{SO}_{4}\right)_{2} \cdot 6 \mathrm{H}_{2} \mathrm{O}$ and $\mathrm{MnSO}_{4}$ using deionized water as a solvent by the slow evaporation technique. Good quality crystals were harvested after 15 days. Photograph of mixed crystals is shown in Fig. 1.

\subsection{Characterization techniques}

The FT-IR spectra were recorded using AVATAR $330 \mathrm{FT}$-IR instrument using $\mathrm{KBr}$ pellet technique in the rang $400-4000 \mathrm{~cm}^{-1}$. The powder X-ray diffraction was performed by using Philips Xpert Pro Triple-axis X-ray diffractometer. The single crystal XRD was recorded using Bruker AXS (Kappa Apex II) Xray diffractometer which emplys graphite monochromated MoKa. The structure was solved and refined by full matric least squares on $\mathrm{F}^{2}$ with Wingx software package ${ }^{6}$ utilizing SHELXS- $97^{7}$ and SHELXL- $97^{8}$ modules. The plots for the structures were created with DIAMOND Software ${ }^{9}$. The morphologies of the samples were recorded by using a JEOL JSM 5610 LV scanning electron microscope with a resolution of $3.0 \mathrm{~nm}$, accelerating voltage 20 $\mathrm{kV}$ and maximum magnification $\mathrm{x}=3,00.000$ AAA, technique was recorded using VARIAN Model SPECTRA 220 Spectrometer in acetone - air flame. The molar proportions of the magnesium and zinc present in the mixed crystals are calculated using AAS and ICP studies.

To reveal the crystalline perfection of the grown crystals, a multicrystal X-ray diffraction (MCD) developed at National Physical Laboratory ${ }^{10}$ has been used to record highresolution rocking or diffraction curves. The well - collimated and monochromated $\mathrm{Mo} \mathrm{Ka}_{1}$ beam obtained from the three monochromator $\mathrm{Si}$ crystals set in dispersive (+,,$- \quad-)$ configuration has been used as the exploring $X$-ray beam. The specimen crystal is aligned in the $(+,-,-,+)$ configuration. The rocking or diffraction curves (DC) were recorded by changing the glancing angle around the Bragg diffraction peak position. The specimen can be rotated about a vertical axis, which is perpendicular to the plane of diffraction, with minimum angular interval of 0.5 arc s. The diffracted intensity is measured by using a scintillation counter. Before recording the DC, the specimen was first lapped and chemically etched in a non-preferential etchant of water and acetone mixture in $1: 2$ volume ratio.

\section{RESULTS AND DISCUSSION}

3.1 FT-IR Spectral analysis

FT-IR spectrum of mixed crystal is shown in Fig. 2. A broadband appeared at 1,708-1,718 $\mathrm{cm}^{-1}$ indicates that it is due to the coordinated water molecules ${ }^{11}$ in the mixed crystal (KMMS). A very slight shift in some of characteristic vibrational frequencies of pure $\mathrm{K}_{2} \mathrm{Mg}\left(\mathrm{SO}_{4}\right)_{2} \cdot 7 \mathrm{H}_{2} \mathrm{O}$ and the mixed crystal $\mathrm{K}_{2} \mathrm{Zn}_{0.84} \mathrm{Mn}_{0.16}\left(\mathrm{SO}_{4}\right)_{2} \cdot 6 \mathrm{H}_{2} \mathrm{O}$ are observed because of lattice stress developed as a result of incorporation of $\mathrm{Mn}$ (II)- into the crystalline matrix. Important characteristic frequencies of the pure and studied mixed crystals are displayed in Table.1.

\subsection{SEM, EDS and AAS analysis}

The effect of the incorporation of $\mathrm{Mn}$ (II)- in the surface morphology of $\mathrm{K}_{2} \mathrm{Mg}\left(\mathrm{SO}_{4}\right)_{2} \cdot 6 \mathrm{H}_{2} \mathrm{O}$ crystal faces reveals the highest surface roughness which could be due to bunch steps or even macro steps (Fig. 3). The presence of manganese in the crystal lattice is confirmed by EDS (Fig. 4). The quantity of incorporated Mn(II)- into the Tutton's salt in estimated to be $2.5 \mathrm{ppm}$ by atomic absorption spectroscopy. It appears that the accommodating capacity of the host crystal is limited and hence only a small quantity is incorporated into the crystalline matrix of $\mathrm{K}_{2} \mathrm{Mg}\left(\mathrm{SO}_{4}\right)_{2} \cdot 7 \mathrm{H}_{2} \mathrm{O}$.

\subsection{Thermal analysis}

The differential thermal analysis shows a sharp endothermic peak at $150^{\circ} \mathrm{C}$ Thermogravimetry curve at a $600^{\circ} \mathrm{C}$ shows the residual mass obtained is $75 \%$. Thermogravimetry and differential thermal analysis reveals that no phase transitions between $150^{\circ} \mathrm{C}$ to $460^{\circ} \mathrm{C}$. (Fig. 5). The endothermic peak around $150^{\circ} \mathrm{C}$ could be due to dehydration of Tutton's salt. Another peak around $460^{\circ} \mathrm{C}$ may be due to the decomposition of the residue.

\subsection{UV - visible spectra}

The UV-visible spectrum of the mixed crystal reveals high transmittance in the visible region and the lower cut - off wavelength is observed at $\sim 370 \mathrm{~nm}$. The concentration of absorbing species can be determined using the KubelkaMunk equation ${ }^{12}$, correlating reflectance and concentration,

$$
F(R)=(1-R)^{2} / 2 R=\alpha / s=A c / s
$$

where $F(R)$ is Kubelka-Munk function, $R$ is the reflectance of the crystal and $S$ is scattering coefficient, $A$ is the absorbance and $c$ is concentration of the absorbing species. The direct band gap energy obtained from the intercept of the resulting straight line with the 
energy axis at $[F(R) h v]^{2}=0$ is deduced as $5.09 \mathrm{eV}$ (Fig. 6).

\subsection{Powder XRD analysis}

The X-ray diffractogram shows many diffraction peaks. The experimental and simulated indexed powder XRD pattern of the mixed crystal KMMS are shown in fig. 7 . It appears that there is a general agreement of the both XRDs with varied intensity patterns. The well defined Bragg's peaks at specific $2 \theta$ angles show good crystallinity of the materials.

\subsection{Single crystal XRD analysis}

Crystal composition of mixed crystal as determined by single crystal XRD is $\mathrm{K}_{2} \mathrm{Mg}_{0.78} \mathrm{Mn}_{0.22}\left(\mathrm{SO}_{4}\right)_{2} \cdot 6 \mathrm{H}_{2} \mathrm{O}$. The structure of KMMS is found to be monoclinic and it belongs to $\mathrm{P} 2{ }_{1} / \mathrm{c}$ space group as that of the parent Tutton's salt. The ORTEP and packing diagrams are given in Fig. 8. These lattice parameters closely match the previous studies of structure determination of Tutton's salt mixed crystals ${ }^{4,5}$ and the pure $\mathrm{K}_{2} \mathrm{Mg}\left(\mathrm{SO}_{4}\right)_{2} \cdot 6 \mathrm{H}_{2} \mathrm{O}^{13}$ (Table 2). The crystal data and structure refinement of KMMS are given in Table. 3. Slight changes are observed in the interatomic distances of the mixed crystal and pure $\mathrm{K}_{2} \mathrm{Mg}\left(\mathrm{SO}_{4}\right)_{2} \cdot 6 \mathrm{H}_{2} \mathrm{O}^{13}$. The $\mathrm{K}-\mathrm{O}$ bond distance is $\sim 2.9 \AA$ for the pure $\mathrm{K}_{2} \mathrm{Mg}\left(\mathrm{SO}_{4}\right)_{2} \cdot 6 \mathrm{H}_{2} \mathrm{O}$ and in KMMS it falls in between 2.7218 (13) and 3.2995 (17) $\AA$. The $\mathrm{Mg} / \mathrm{Mn}-\mathrm{O}$ bond distance varies between 2.0508(13) and 2.1269(12) $\AA$ in KMMS mixed crystals. It is comparable with $\mathrm{Zn} / \mathrm{Mn}-\mathrm{O}$ bond distance in $\mathrm{KZMS}^{5}$ and $\mathrm{Zn} / \mathrm{Mg}-\mathrm{O}$ bond distance in zinc magnesium ammonium sulfate hexahydrate ${ }^{4}$ mixed crystals. The bond lengths and angles in the sulfate group of $\mathrm{K}_{2} \mathrm{Mg}\left(\mathrm{SO}_{4}\right)_{2} \cdot 6 \mathrm{H}_{2} \mathrm{O}$ are close to the tetrahedral pattern ( $\mathrm{S}-\mathrm{O}=1.442$ to $1.507 \AA$ and O-S-O bond angle $107^{\circ}$ to $112^{\circ}$ ) and in the new mixed crystal the corresponding values are $1.4727(12) \AA$ and $108.10^{\circ}$ to $110.37^{\circ}$ respectively. The $\mathrm{O}-\mathrm{Mg}-\mathrm{O}$ bond angles for KMMS mixed crystal falls in the range from $89.13^{\circ}$ to $90.87^{\circ}$ which is comparable to that in $\mathrm{K}_{2} \mathrm{Mg}\left(\mathrm{SO}_{4}\right)_{2} \cdot 6 \mathrm{H}_{2} \mathrm{O}$ and $\mathrm{Zn}_{x} \mathrm{Mg}_{(1-\mathrm{x})}\left(\mathrm{NH}_{4}\right)_{2}\left(\mathrm{SO}_{4}\right)_{2}$. The Mg-O and $\mathrm{O}-\mathrm{H}$ bond lengths of KMMS mixed crystal lie between $2.0508 \AA-2.1269 \AA$ and $0.810 \AA-0.859 \AA$ respectively, whereas in $\mathrm{Zn}_{\mathrm{x}} \mathrm{Mg}_{(1-\mathrm{x})}\left(\mathrm{NH}_{4}\right)_{2}\left(\mathrm{SO}_{4}\right)_{2} \cdot 6 \mathrm{H}_{2} \mathrm{O}$ mixed crystal it ranges from $2.0512 \AA$ to $2.0904 \AA$ and 0.858 $\AA$ to $0.862 \AA$ respectively.

\subsection{HRXRD}

Fig. 9 shows the diffraction curve (DC) for a typical KMMS specimen single crystal recorded for (123) diffracting planes in symmetrical Bragg geometry using MoKa radiation. As seen in the figure, the curve is quite board with FWHM (Full width at half maximum) value 520 arc sec. The top of the diffraction curve is not smooth and indicates multiple peaks. The multiple peaks with large value of FWHM indicates that the specimen contains many mosaic blocks which are misoriented to each other with their adjacent regions by a few tens of arc sec as observed in benzimedazole single crystals grown by vertical Bridgman technique ${ }^{14}$. Impurities present in the raw material and thermal and/or mechanical fluctuations during the growth process may be responsible for such features of diffraction curve. However in the case of $\mathrm{KZMS}^{5}$ the diffraction curve dose not contain any additional peak and indicates the absence of clustering of defects at microscopic level (FWHM is equal to 48 arc s) and fairly good crystalline perfection.

\section{CONCLUSION}

In the present study, the synthesis, characterisation and crystal structure of a new mixed crystal $\mathrm{K}_{2} \mathrm{Mg}_{0.78} \mathrm{Mn}_{0.22}\left(\mathrm{SO}_{4}\right)_{2} \cdot 6 \mathrm{H}_{2} \mathrm{O}$ (KMMS), structurally similar to $\mathrm{K}_{2} \mathrm{Mg}\left(\mathrm{SO}_{4}\right)_{2} \cdot 6 \mathrm{H}_{2} \mathrm{O}$ have been studied. Single crystal XRD studies reveal that the bond lengths, and bond angles of the new mixed crystal KMMS are comparable with that of $\mathrm{Zn}_{0.54} \mathrm{Mg}_{0.46}\left(\mathrm{NH}_{4}\right)_{2}\left(\mathrm{SO}_{4}\right)_{2} .6 \mathrm{H}_{2} \mathrm{O}$ and $\mathrm{K}_{2} \mathrm{Zn}_{0.84} \mathrm{Mn}_{0.16}\left(\mathrm{SO}_{4}\right)_{2} \cdot 6 \mathrm{H}_{2} \mathrm{O}$. The incorporation of $\mathrm{Mn}(\mathrm{II})$ - in the crystalline matrix of $\mathrm{K} 2 \mathrm{Mg}\left(\mathrm{SO}_{4}\right)_{2} \cdot 6 \mathrm{H}_{2} \mathrm{O}$ is confirmed by EDS and AAS. A slight shift in the vabrational patterns could be due to the incorporation of $\mathrm{Mn}$ (II)- in to the Tutton's salt crystal lattice. Highest surface roughness in the SEM micrographs of KMMS mixed crystal is due to the $\mathrm{Mn}$ (II)incorporation. High resolution X-ray diffraction curve shows a broad single peak, revealing that the KMMS mixed crystal contains many mosaic blocks which are completely misoriented to each other. 
Table 1: FT-IR Vibrational frequencies $\left(\mathrm{cm}^{-1}\right)$

\begin{tabular}{|c|c|c|c|c|c|}
\hline System & $\begin{array}{l}\mathrm{SO}_{4}{ }^{2-} \\
\text { Symmetrical } \\
\text { bending } \\
\text { modes }\left(\mathrm{cm}^{-1}\right)\end{array}$ & $\begin{array}{c}\mathrm{SO}_{4}{ }^{2-} \\
\text { Asymmetric } \\
\text { bending } \\
\text { modes }\left(\mathrm{cm}^{-1}\right)\end{array}$ & $\begin{array}{c}\mathrm{SO}_{4}{ }^{2-} \\
\text { Symmetric } \\
\text { stretching } \\
\text { modes } \\
\left(\mathrm{cm}^{-1}\right)\end{array}$ & $\begin{array}{c}\mathrm{SO}_{4}^{2-} \\
\text { Asymmetric } \\
\text { stretching } \\
\text { modes }\left(\mathrm{cm}^{-1}\right)\end{array}$ & Reference \\
\hline Tutton's salt & 451 & 631 & 983 & 1098,1142 & [13] \\
\hline $\mathrm{K}_{2} \mathrm{Zn}_{0.84} \mathrm{Mn}_{0.16}\left(\mathrm{SO}_{4}\right)_{2 .} 6 \mathrm{H}_{2} \mathrm{O}$ & 459 & 618 & 983 & 1096,1122 & [5] \\
\hline $\mathrm{K}_{2} \mathrm{Mg}_{0.78} \mathrm{Mn}_{0.22}\left(\mathrm{SO}_{4}\right)_{2} \cdot 6 \mathrm{H}_{2} \mathrm{O}$ & 455 & 630 & 983 & 1096,1146 & Present work \\
\hline $\mathrm{Zn}_{0.54} \mathrm{Mg}_{0.46}\left(\mathrm{NH}_{4}\right)_{2}\left(\mathrm{SO}_{4}\right)_{2} \cdot 6 \mathrm{H}_{2} \mathrm{O}$ & 460 & 621 & 980 & 1044,1138 & [4] \\
\hline
\end{tabular}

Table 2: Cell parameters

\begin{tabular}{|c|c|c|c|c|c|}
\hline System & a $(\dot{\AA})$ & $\mathbf{b}(\dot{\mathbf{A}})$ & $\mathbf{c}(\mathbf{\AA})$ & $\mathbf{V}\left(\dot{\AA}^{3}\right)$ & Reference \\
\hline $\mathrm{K}_{2} \mathrm{Mg}\left(\mathrm{SO}_{4}\right)_{2} \cdot 6 \mathrm{H}_{2} \mathrm{O}$ & 9.029 & 12.204 & 6.147 & 654.8 & {$[13]$} \\
\hline $\mathrm{K}_{2} \mathrm{Zn}_{0.84} \mathrm{Mn}_{0.16}\left(\mathrm{SO}_{4}\right)_{2} \cdot 6 \mathrm{H}_{2} \mathrm{O}$ & 9.019 & 12.192 & 6.134 & 652.1 & {$[5]$} \\
\hline $\mathrm{K}_{2} \mathrm{Mg}_{0.78} \mathrm{Mn}_{0.22}\left(\mathrm{SO}_{4}\right)_{2} \cdot 6 \mathrm{H}_{2} \mathrm{O}$ & 9.0940 & 12.2740 & 6.1380 & 662.3 & Present work \\
\hline $\mathrm{Zn}_{0.54} \mathrm{Mg}_{0.46}\left(\mathrm{NH}_{4}\right)_{2}\left(\mathrm{SO}_{4}\right)_{2} \cdot 6 \mathrm{H}_{2} \mathrm{O}$ & 9.2557 & 12.534 & 6.221 & 690.6 & {$[4]$} \\
\hline
\end{tabular}

Table 3: Crystal data and structure refinement for KMMS

\begin{tabular}{|c|c|}
\hline $\begin{array}{l}\text { Empirical formula } \\
\text { Molecular formula }\end{array}$ & $\begin{array}{c}\mathrm{H}_{6} \mathrm{KMg}_{0.39} \mathrm{Mn}_{0.11} \mathrm{O}_{7} \mathrm{~S} \\
\mathrm{~K}_{2} \mathrm{Mg}_{0.78} \mathrm{Mn}_{0.22}\left(\mathrm{SO}_{4}\right)_{2} \cdot 6 \mathrm{H}_{2} \mathrm{O}\end{array}$ \\
\hline Formula weight & 204.73 \\
\hline Temperature & $293(2) \mathrm{K}$ \\
\hline Wavelength & $0.71073 \AA$ \\
\hline Crystal system, space group & Monoclinic, $P 2_{1} / \mathrm{c}$ \\
\hline Unit cell dimensions & $\begin{array}{c}\mathrm{a}=6.1530(2) \AA, \alpha=90^{\circ} \\
\mathrm{b}=12.2740(3) \AA, \beta=104.8190(10)^{\circ} \\
c=9.0940(2) \AA 3, \gamma=90^{\circ}\end{array}$ \\
\hline Volume & $662.33(3) \AA^{3}$ \\
\hline Z, Calculated density & 4, $2.053 \mathrm{Mg} / \mathrm{m}^{3}$ \\
\hline Absorption coefficient & $1.335 \mathrm{~mm}^{-1}$ \\
\hline $\mathrm{F}(000)$ & 418 \\
\hline Crystal size & $0.30 \times 0.30 \times 0.20 \mathrm{~mm}$ \\
\hline Theta range for data collection & 2.85 to $24.99 \mathrm{deg}$ \\
\hline Limiting indices & $-6<=\mathrm{h}<=7,-14<=\mathrm{k}<=14,-10<=\mathrm{l}<=10$ \\
\hline Reflections collected / unique & $5448 / 1171[R($ int $)=0.0390]$ \\
\hline Completeness to theta $=24.99$ & $100.0 \%$ \\
\hline Absorption correction & Semi-empirical from equivalents \\
\hline Max. and min. transmission & 0.7968 and 0.6486 \\
\hline Refinement method & Full-matrix least-squares on $\mathrm{F}^{2}$ \\
\hline Data / restraints / parameters & $1171 / 10 / 115$ \\
\hline Goodness-of-fit on $\mathrm{F}^{2}$ & 1.090 \\
\hline Final R indices [I>2sigma(I)] & $\mathrm{R} 1=0.0203, \mathrm{wR} 2=0.0561$ \\
\hline $\mathrm{R}$ indices (all data) & $\mathrm{R} 1=0.0220, \mathrm{wR} 2=0.0571$ \\
\hline Extinction coefficient & $0.128(5)$ \\
\hline Largest diff. peak and hole & 0.260 and -0.292 e. $A^{-3}$ \\
\hline
\end{tabular}

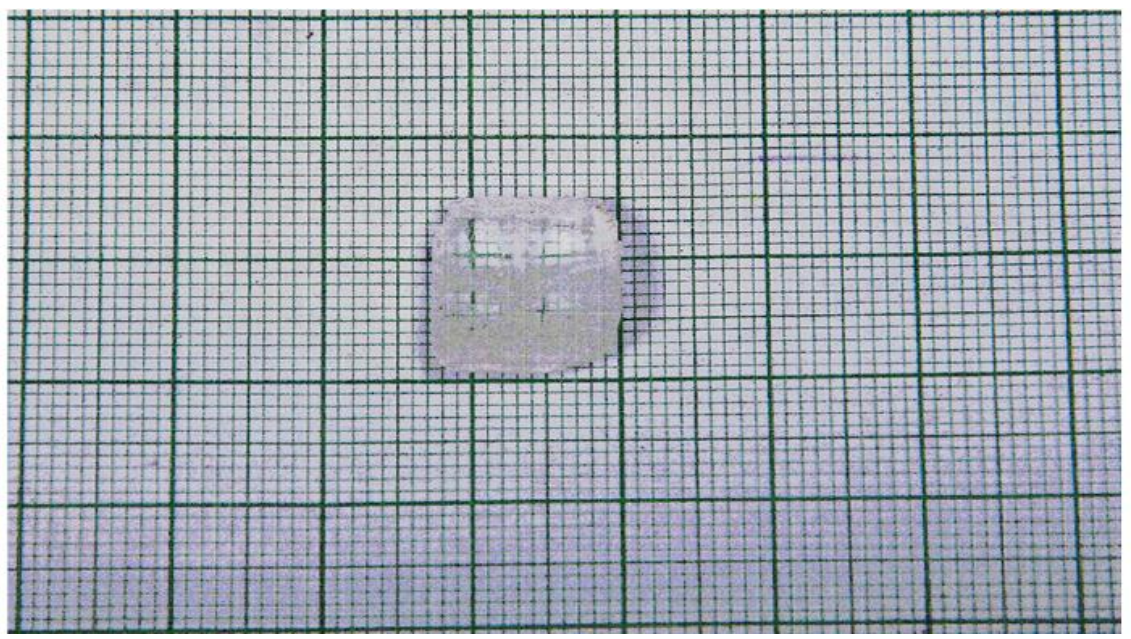

Fig. 1: Photograph of KMMS mixed crystal 


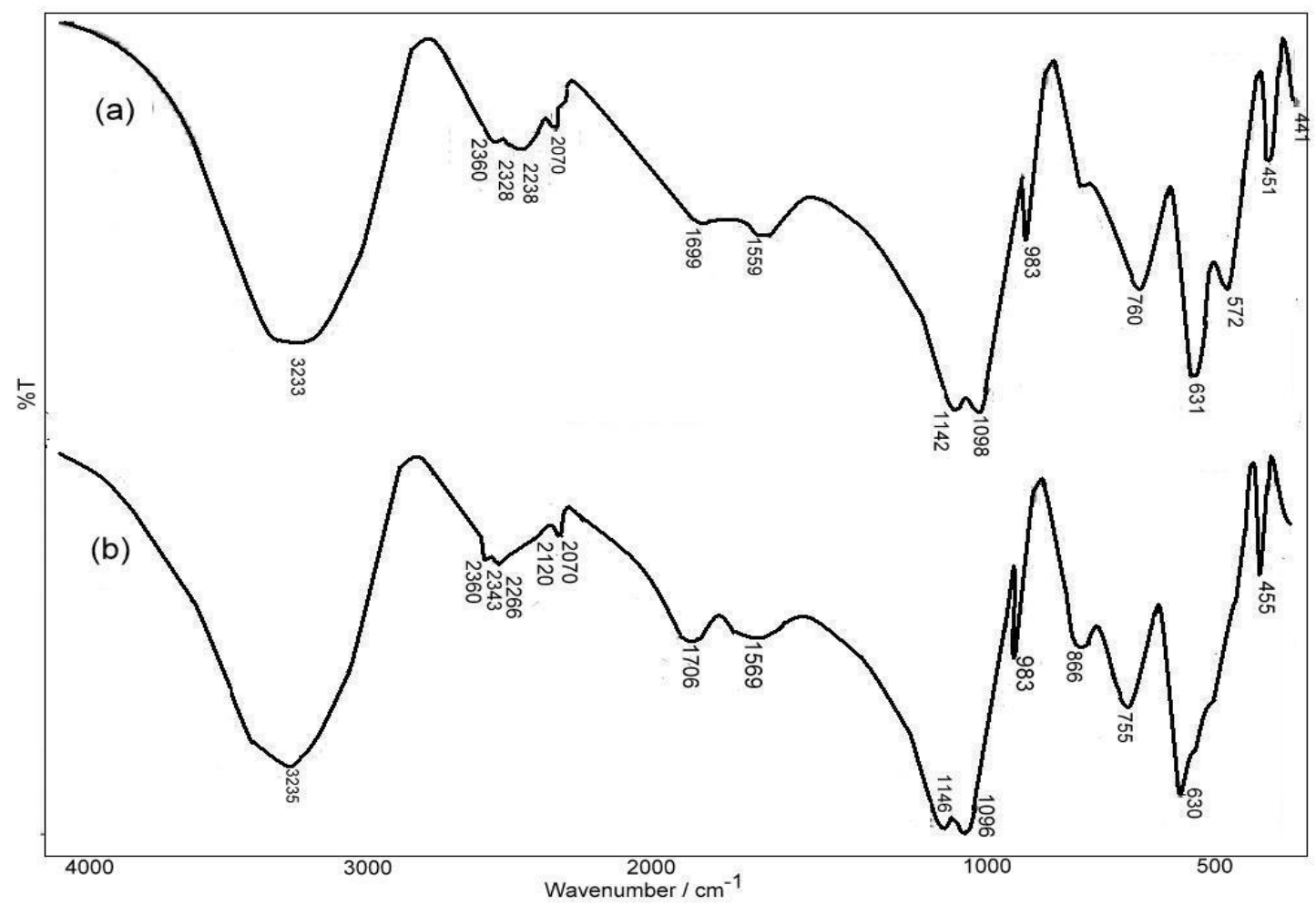

Fig. 2: FT-IR spectra of (a) Pure and (b) KMMS mixed crystal
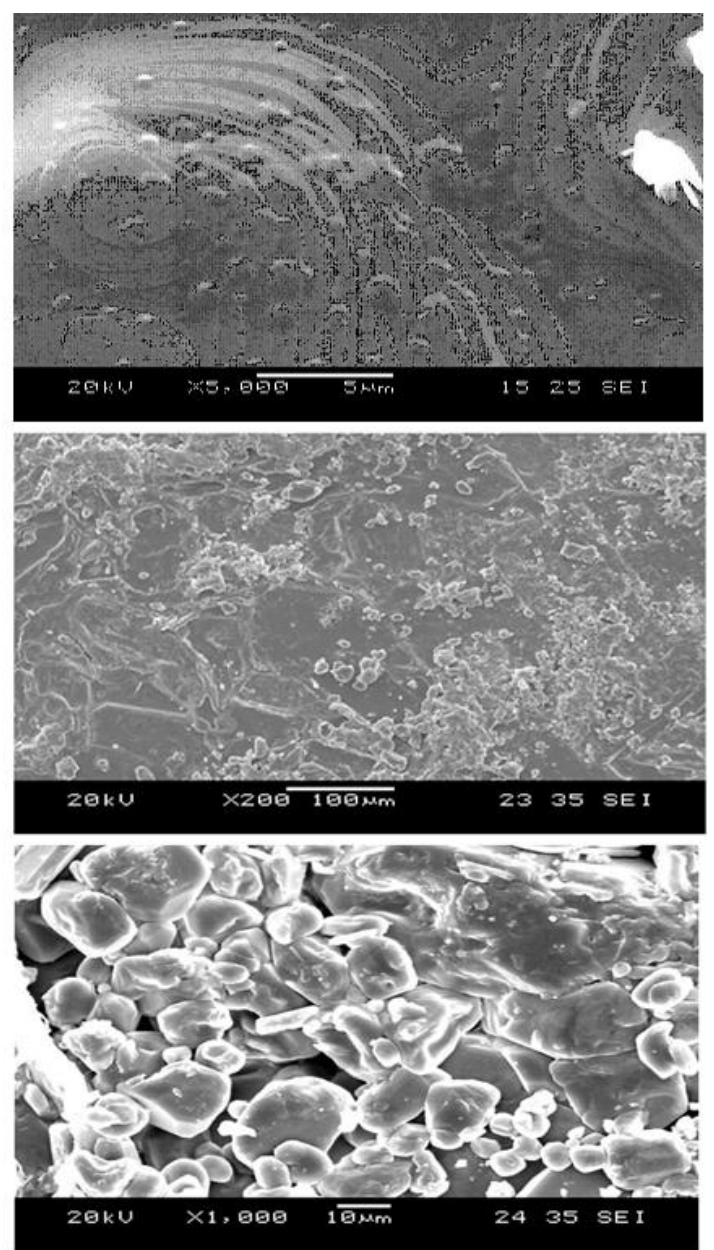

Fig. 3: SEM mircographs of KMMS mixed crystal 


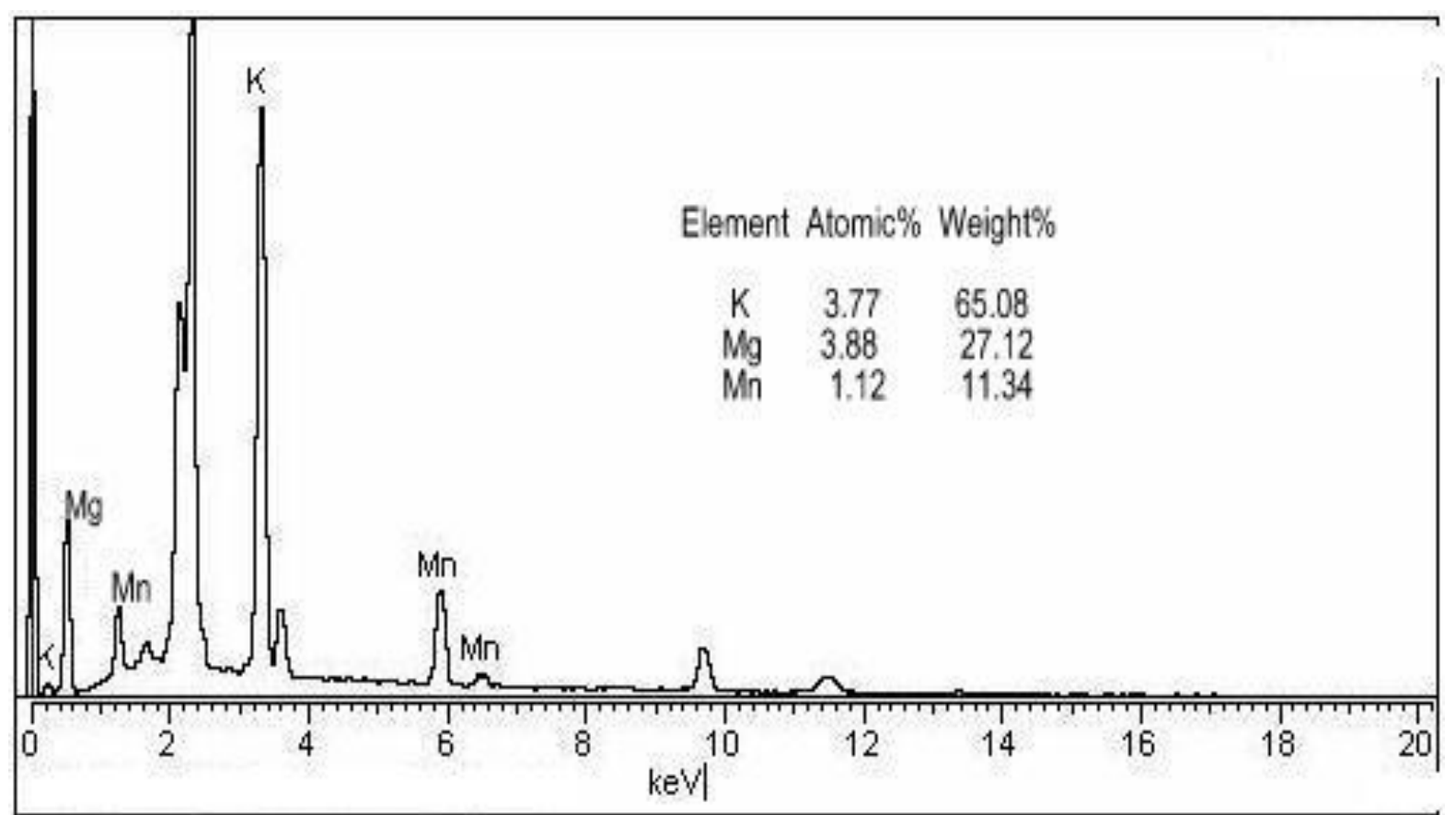

Fig. 4: EDS spectrum of KMMS mixed crystal

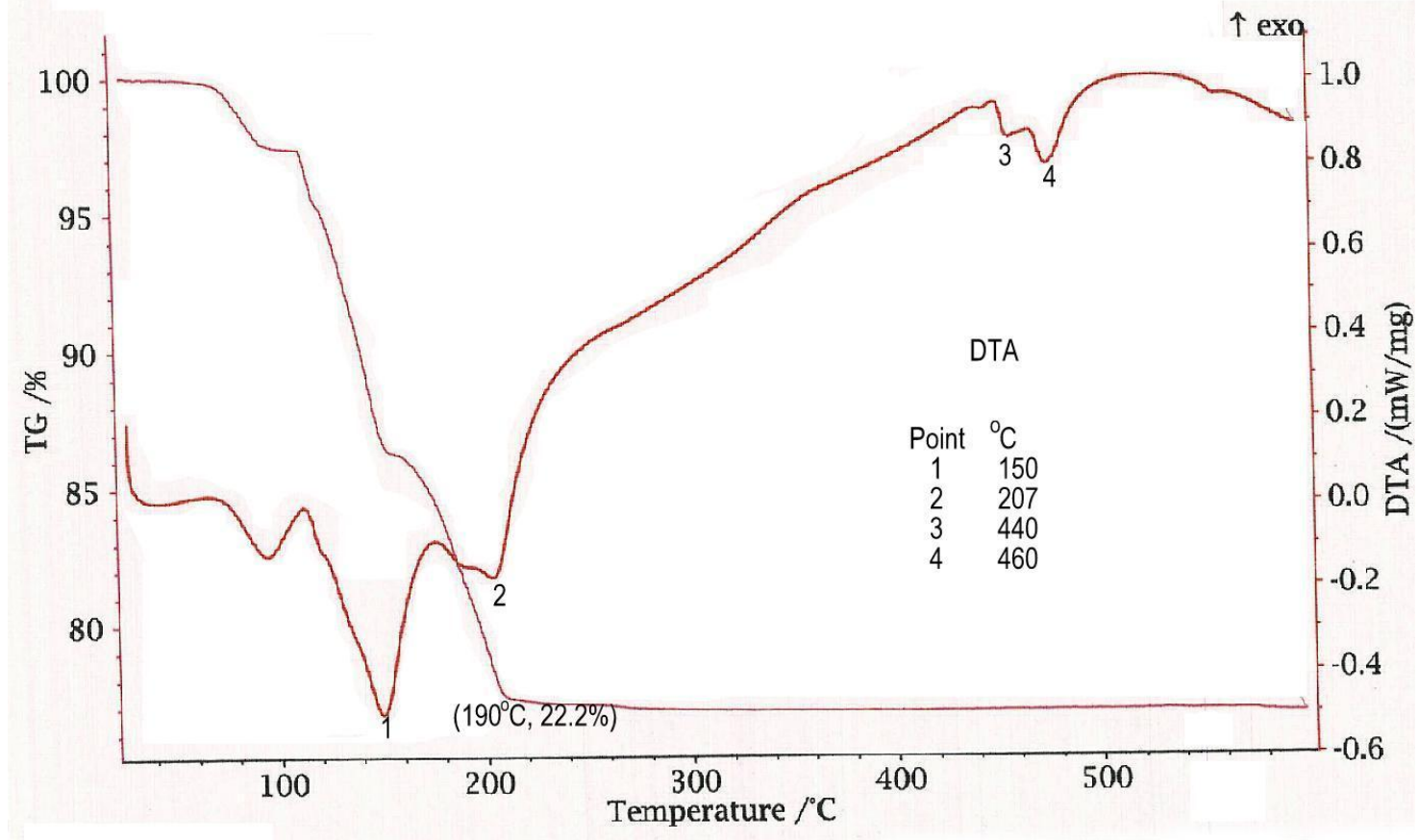

Fig. 5: TG/DTA curve of KMMS 


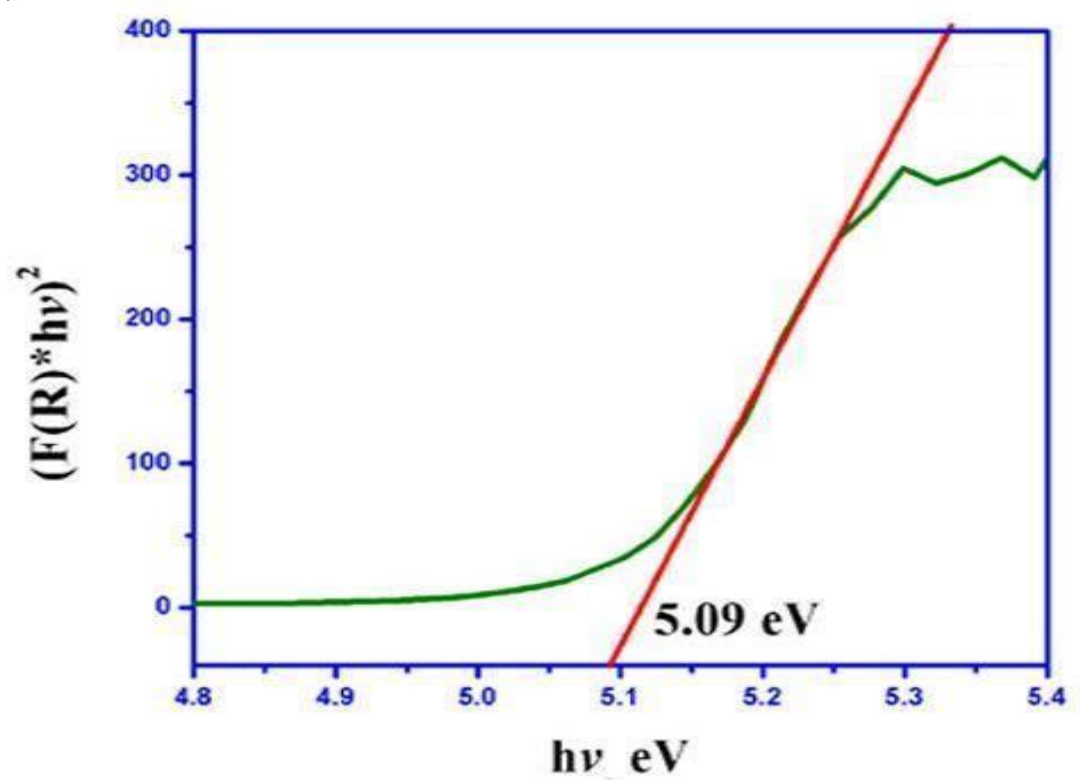

Fig. 6: Band gap energy curve of KMMS

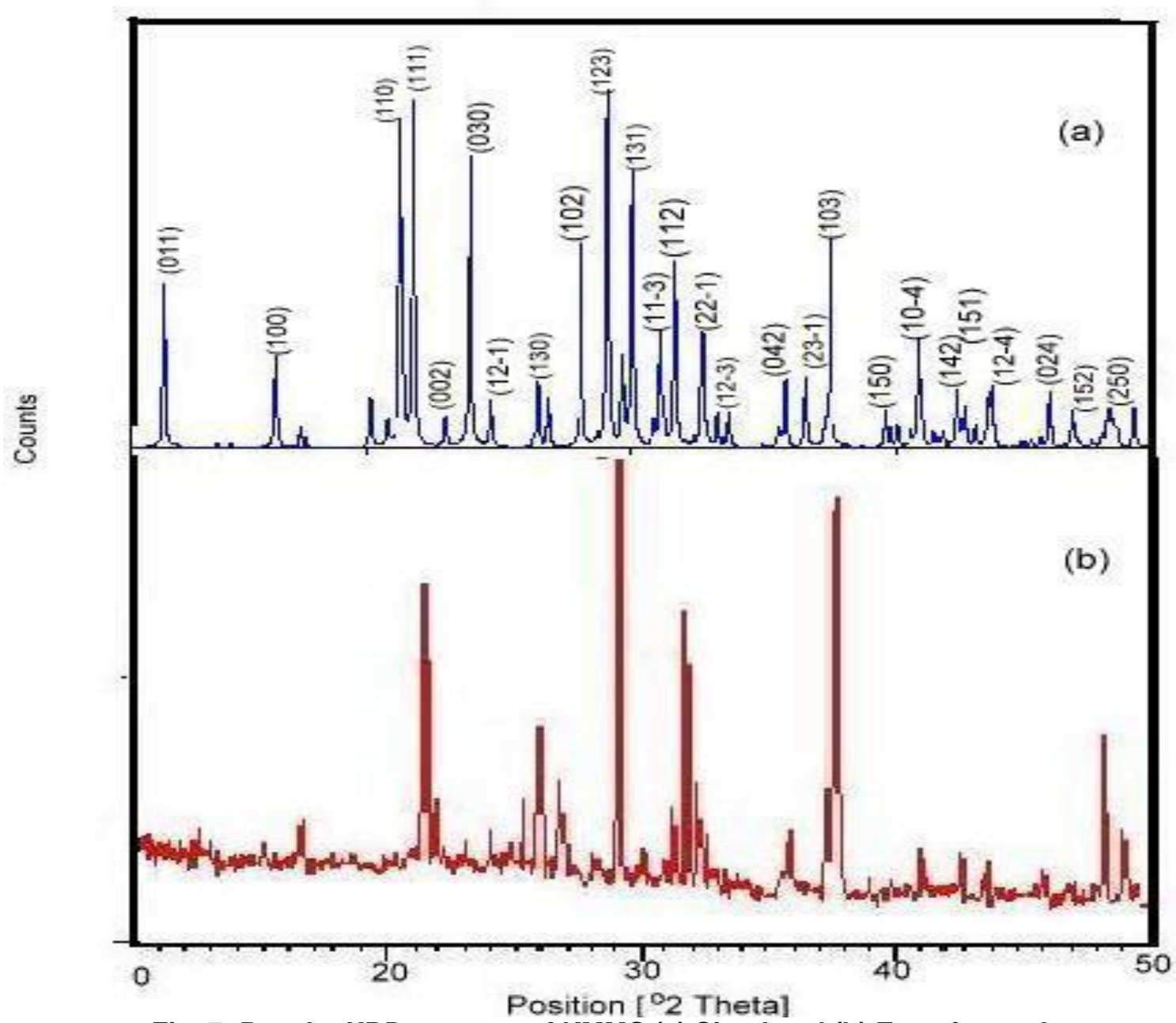

Fig. 7: Powder XRD patterns of KMMS (a) Simulated (b) Experimental 


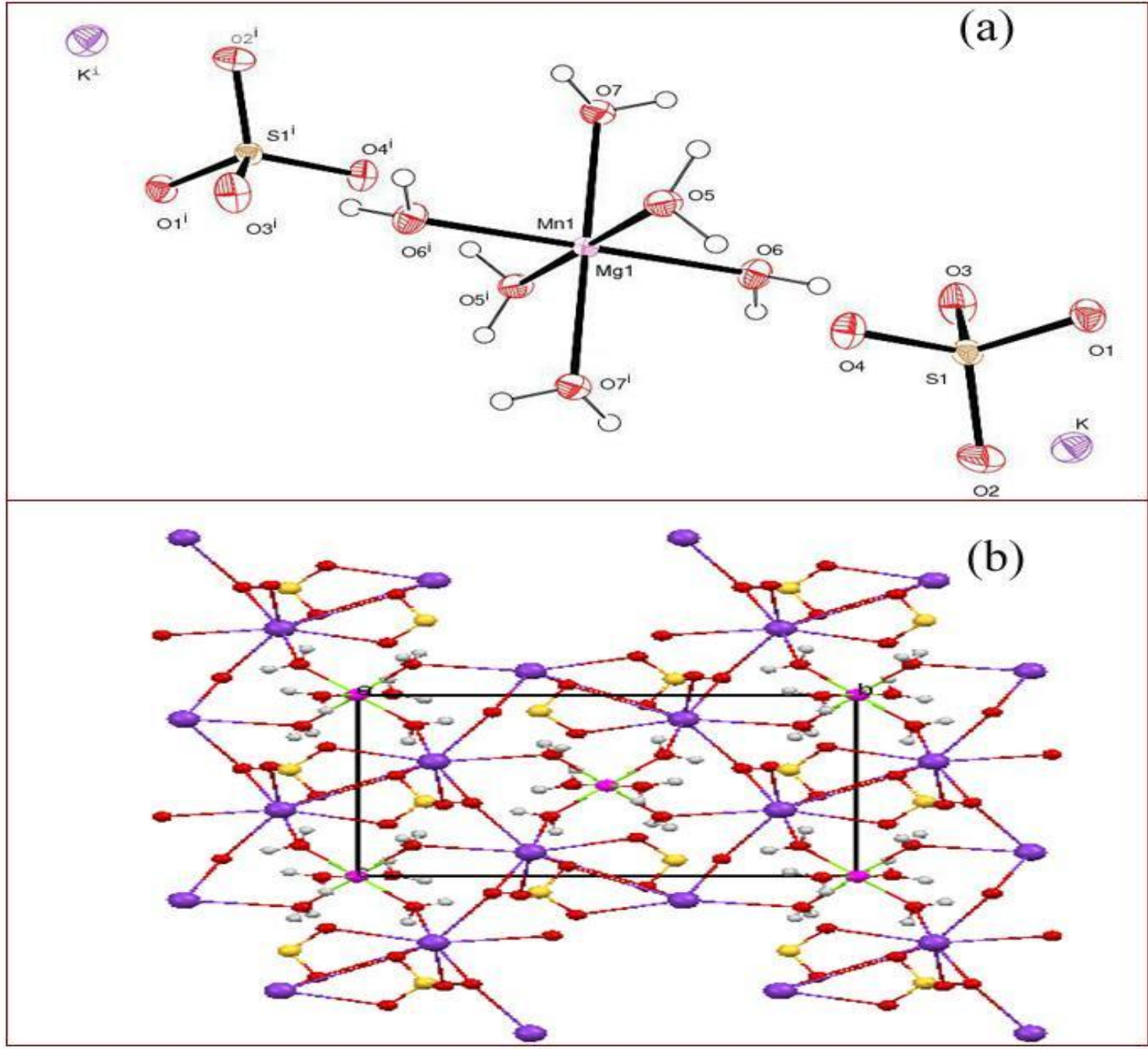

Fig. 8: ORTEP and packing diagram of KMMS mixed crystal

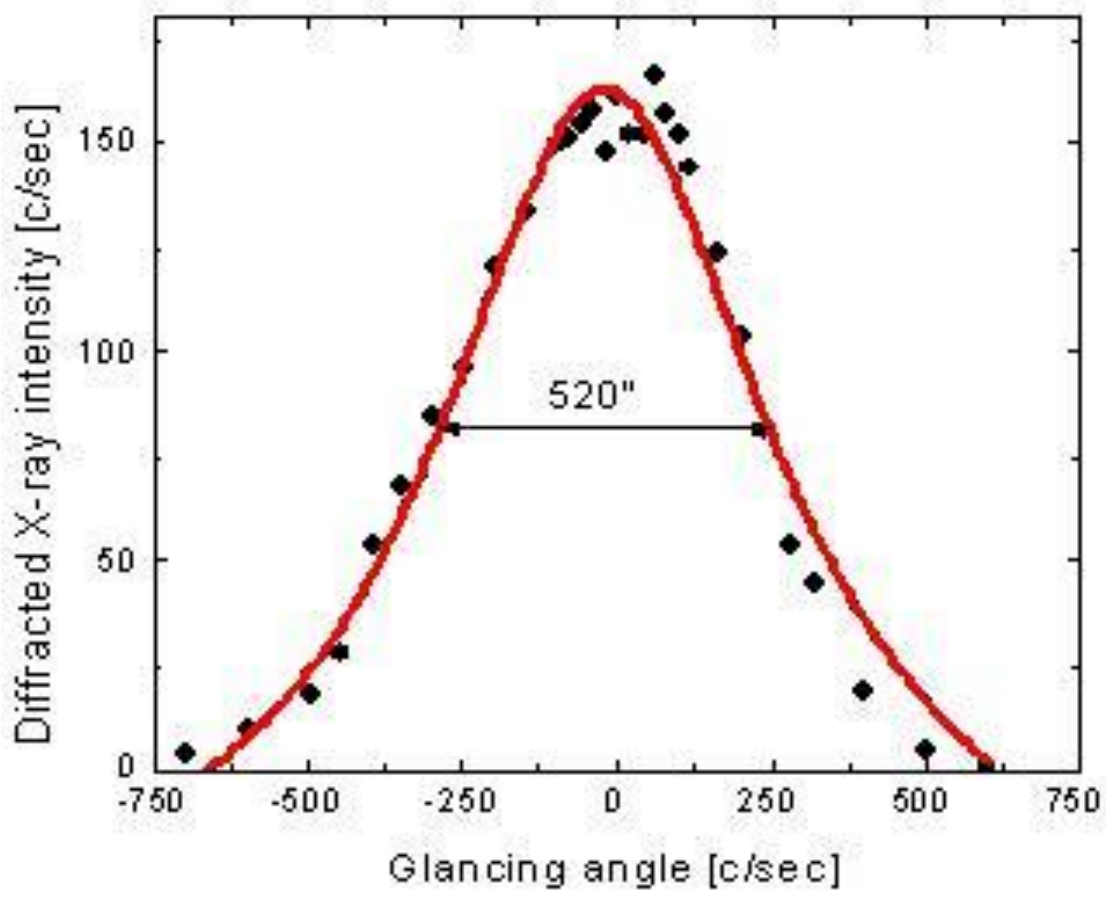

Fig. 9: HRXRD diffraction curve of KMMS mixed crystal 


\section{REFERENCES}

1. Tutton AE. Proc Royal Soc. London 67. 1990;58-84.

2. Margulis TN, Templeton $\mathrm{DH}$ and Kristallogr Z. 1962;117:344-375.

3. Dhandapani $M$, Thyagu $L$, Arunprakash $P$, Amirtha ganesan $G$, Kandhaswamy MA and Srinivasan V. Crystal Research and Technology. 2006;41:321-331.

4. Ramasamy G, Bhagavannarayana G, Subbiah Meenakshisundaram and Madhurambal G. J Cryst Growth. 2012;352:147-152.

5. Vijila Manonmani J, Bhagavannarayana G, Ramasamy G, Subbiah Meenakshisundaram, and Amutha M. Spectrochimca Acta A. 2014;117:9-12.

6. Farrugia LJ. J Cryst Growth. 1982;58:495.

7. Sheldric GM. SHELXS. A computer program for crystal structure solution,
University of Gottingen, Germany. 1997.

8. Sheldric GM and SHELXL. A computer program for crystal structure determination, University of Gottingen, Germany. 1997.

9. Brandenburg $\mathrm{K}$ and Putz $\mathrm{H}$. DIAMOND -3 University of Bonn, Germany. 2004.

10. Lal K and Bhagavannarayana G. J Appl Crystallogr. 1989;22:209.

11. Nakamoto K. Raman Infrared spectra of inorganic coordination compounds, New Yark, Wiley. 1986;4:242-244.

12. Kubelka P. J Opt Soc Am. 1948;38:448-457.

13. Kannan KK, Viswamitra MA and Kristallogr Z. 1965;122:161-174.

14. Vijayn N, Bhagavannarayana G, Ramesh Babu R, Gopalakrishnan R, Maurya KK and Ramasamy P. Crystal Growth and Design. 2006;41:784-789. 